\title{
Rancang Bangun Rekomendasi Penerima Bantuan Sosial Berdasarkan Data Kesejahteraan Rakyat
}

\author{
Erliyan Redy Susanto1, ${ }^{1,}$, Ajeng Savitri Puspaningrum², ${ }^{2}$ eneng ${ }^{3}$ \\ Fakultas Teknik dan Ilmu Komputer, ${ }^{1}$ Sistem Informasi, ${ }^{2}$ Teknik Komputer, ${ }^{3}$ Informatika, Universitas \\ Teknokrat Indonesia, Bandar Lampung, Indonesia \\ Email: 1,"erliyan.redy@teknokrat.ac.id, ${ }^{2}$ ajeng.savitri@teknokrat.ac.id, ${ }^{3}$ neneng@teknokrat.ac.id \\ *) Email Penulis Utama
}

\begin{abstract}
Abstrak-Akibat adanya pandemi Covid-19 yang melanda dunia menyebabkan banyak negara mengalami berbagai krisis diantaranya ekonomi, sosial, agama, pendidikan dan sebagainya. Negara miskin, negara berkembang hingga negara maju berupaya untuk mengatasi berbagai dimensi yang dipengaruhi oleh krisis pandemi covid-19 ini. Bahkan negara Indonesia termasuk yang terdampak cukup parah akibat krisis ini. Masalah perekonomian dipandang sebagai masalah utama yang harus segera dicarikan solusi untuk mengatasi krisis ini. Bahkan pemerintah sudah membuat berbagai kebijakan strategis guna memulihkan perekonomian di Indonesia. Sebagai bagian dari tanggung jawab pemerintah dalam memulihkan perekonomian negara serta amanat undangundang dasar negara 1945 untuk mensejakterakan rakyat maka pemerintah memberikan bantuan sosial dalam penanggulangan ekonomi. Oleh karena itu pemerintah membuat kebijakan dengan melaksanakan 7 program bantuan diantaranya bantuan sembako, bantuan sosial tunai, bantuan langsung tunai pada dana desa, listrik gratis, kartu prakerja, subsidi gaji karyawan dan bantuan langsung tunai bagi usaha mikro. Akan tetapi banyak media yang memberitakan bahwa upaya bantuan sosial akibat dampak covid-19 yang dilakukan pemerintah banyak yang tidak tepat sasaran. Apabila hal ini benar-benar terjadi maka sasaran pemerintah untuk memperbaiki ekonomi tidak sesuai yang diharapkan. Pada artikel ini berfokus pada program bantuan langsung tunai. Masalah seperti ketidaktepatan sasaran penerimaan bantuan ini tentunya harus segera diatasi dan dicari solusinya agar tidak terulang lagi pada program-program bantuan di masa yang akan datang. Menjawab masalah ini maka perlu adanya suatu sistem yang dapat memberikan informasi yang akurat tentang keadaan masyarakat sehingga masalah tersebut segera diatasi. Oleh karena itu maka pemerintah perlu memiliki strategi yang tepat dalam menentukan kriteria untuk mengukur kelayakan dalam menerima bantuan sosial akibat dampak covid-19. Tujuan dari penelitian ini adalah membangun suatu model untuk memberikan rekomendasi penerima bantuan sosial akibat dampak covid-19 dengan studi kasus pada rukun tetangga yang berada di wilayah Kota Bandar Lampung. Dalam artikel ini mepaparkan hasil penelitian tentang penggunaan metode Simple Additive Weighting untuk menentukan prioritas penerima bantuan sosial akibat dampak Covid-19 berdasarkan data indikator kesejahteraan rakyat Provinsi Lampung tahun 2019. Bahasa pemrograman berbasis web menggunakan bahasa PHP dan database MySQL digunakan untuk membangun purwa rupa software rekomendasi penerima bantuan sosial akibat dampak covid-19. Sedangkan hasil penelitian adalah purwa rupa dalam bentuk aplikasi komputer berbasis web yang dapat memberi rekomendasi masyarakat penerima bantuan sosial berdasarkan data kesejahteraan rakyat.
\end{abstract}

Kata Kunci: Covid-19, Simple Additive Weighting, bantuan sosial, kesejahteraan rakyat, Bandar Lampung

\begin{abstract}
As a result of the Covid-19 pandemic that has hit the world, many countries have experienced various crises including economic, social, religious, educational and so on. Poor countries, developing countries to developed countries are trying to overcome the various dimensions affected by the Covid-19 pandemic crisis. Even the country of Indonesia is one of the most severely affected by this crisis. The economic problem is seen as the main problem that must immediately find a solution to overcome this crisis. Even the government has made various strategic policies to restore the economy in Indonesia. As part of the government's responsibility in restoring the country's economy and the mandate of the 1945 constitution to make the people better, the government provides social assistance in overcoming the economy. Therefore the government made a policy by implementing 7 assistance programs including basic food assistance, cash social assistance, direct cash assistance to village funds, free electricity, pre-employment cards, employee salary subsidies and direct cash assistance for micro businesses. However, many media have reported that many social assistance efforts due to the impact of Covid-19 have not been on target. If this really happens, the government's goal of improving the economy will not be as expected. This article focuses on cash transfer programs. Problems such as the inaccuracy of the target of receiving assistance, of course, must be immediately resolved and solutions sought so that they do not occur again in future aid programs. Answering this problem, it is necessary to have a system that can provide accurate information about the state of society so that the problem can be resolved immediately. Therefore, the
\end{abstract}


government needs to have the right strategy in determining criteria for measuring eligibility for receiving social assistance due to the impact of Covid-19. The purpose of this research is to build a model to provide recommendations for recipients of social assistance due to the impact of Covid-19 with a case study of neighborhoods in the city of Bandar Lampung. This article describes the results of research on the use of the Simple Additive Weighting method to determine the priority of social assistance recipients due to the impact of Covid-19 based on data on indicators of the people's welfare in Lampung Province in 2019. Web-based programming language using PHP and MySQL database is used to build a prototype of recommendation software. recipients of social assistance due to the impact of covid-19. Meanwhile, the research result is a prototype in the form of a web-based computer application that can provide recommendations for social assistance recipients based on people's welfare data.

Keywords: Covid-19, Simple Additive Weighting, social assistance, people's welfare, Bandar Lampung City

\section{PENDAHULUAN}

Negara wajib menjamin kesejahteraan setiap penduduknya dan setiap penduduk berhak untuk mendapatkan kesejahteraan. Kesejahteraan penduduk memberikan pengaruh yang besar pada sistem politik, ekonomi, dan sebagainya. Tingkat kesejahteraan penduduk pada suatu Negara menunjukan seberapa berhasil suaru Negara dalam mencapai tujuannya. Dalam rangka meningkatkan kesejahteraan penduduk, pemerintah melaksanakan berbagai program peningkatan kesejahteraan penduduk. Namun, terkadang program peningkatan kesejahteraan penduduk tidak berjalan dengan efektif. Hal ini disebabkan tidak tepatnya sasaran yang disebabkan oleh data identifikasi target yang kurang akurat. Seringkali ditemukan terjadi kesalahan dalam menentukan kelayakan penerimaan bantuan. Masalah seperti ketidaktepatan sasaran penerimaan bantuan ini tentunya harus segera diatasi dan dicari solusinya agar tidak terulang lagi pada program-program bantuan di masa yang akan datang.

Akibat adanya pandemi Covid-19 yang melanda dunia menyebabkan banyak negara mengalami berbagai krisis diantaranya ekonomi, sosial, agama, pendidikan dan sebagainya. Negara miskin, negara berkembang hingga negara maju berupaya untuk mengatasi berbagai dimensi yang dipengaruhi oleh krisis pandemi covid-19 ini. Bahkan negara Indonesia termasuk yang terdampak cukup parah akibat krisis ini. Masalah perekonomian dipandang sebagai masalah utama yang harus segera dicarikan solusi untuk mengatasi krisis ini. Bahkan pemerintah sudah membuat berbagai kebijakan strategis guna memulihkan perekonomian di Indonesia. Sebagai bagian dari tanggung jawab pemerintah dalam memulihkan perekonomian negara serta amanat undang-undang dasar negara 1945 untuk mensejakterakan rakyat maka pemerintah memberikan bantuan sosial dalam penanggulangan ekonomi. Masalah ketidaktepatan sasaran penerimaan bantuan seringkali terjadi pada berbagai daerah di Indonesia, tidak terkecuali pada Provinsi Lampung. Bahkan berbagai media online melaporkan bahwa banyak bantuan sosial tidak tepat sasaran [1][2][3]. Apabila hal ini terus dibiarkan maka akan mengakibatkan kerugian negara yang sangat besar. Terlebih apabila dana yang digunakan berasal dari pinjaman luar negeri. Hal ini tentu saja akan berdampak pada perekonomian negara yang semakin berat. Krisis ekonomi dan krisis kepercayaan terhadap pemerintah pasti akan terjadi.

Dalam rangka memperbaiki perekonomian di Indonesia maka pemerintah melalui beberapa kementerian terkait telah membuat kebijakan ekonomi dengan melaksanakan 7 program bantuan. Program bantuan yang dimaksud diantaranya adalah bantuan sembako, bantuan sosial tunai (BST), bantuan langsung tunai (BLT) pada dana desa, listrik gratis, kartu prakerja, subsidi gaji karyawan dan bantuan langsung tunai (BLT) bagi usaha mikro[4]. Dalam penelitian yang dilakukan berfokus pada program BST terdampak Covid-19. Model keputusan yang dikembangkan menggunakan data kesejahteraan rakyat sesuai dengan indikator kesejahteraan rakyat provinsi Lampung 2019.

Tingkat kesejahteraan rakyat menjadi indikator penting bagi pemerintah dalam menentukan siapa saja yang perlu diberikan bantuan[5]. Akan tetapi, sepertinya kesejahteraan rakyat tidak digunakan sebagai indikator dalam menentukan penerima bantuan sosial. Banyak pihak menduga bahwa penilaian terhadap penerima bantuan sosial yang terjadi saat ini bersifat objektif karena hal ini dipengaruhi oleh adanya rasa suka dan tidak suka atau adanya kedekatan hubungan penerima bantuan sosial dengan pihak-pihak yang dianggap bertanggungjawab dalam menentukan data penerima bantuan sosial.

Permasalahan utama dalam penelitian ini adalah bahwa setiap kelurahan diberikan jumlah kuota untuk mengajukan data penerima bantuan sosial terdampak covid-19. Pada kenyataannya banyak masyarakat yang menginginkan bantuan tersebut. Data masyarakat yang akan diajukan harus memiliki beberapa sayarat yaitu terdampak pandemi covid-19 seperti terkena PHK atau terhambat usahanya akibat kebijakan masa pandemi. Oleh karena itu data masyarakat yang akan diajuan sebagai calon penerima BST perlu dianalisis sehingga hasil penilaian akan objektif. 
Dalam hal ini jika dalam melaksanakan program kesejahteraan, pemerintahan ingin melihat atau mengetahui tingkat kesejahteraan kabupaten atau kota maka pemerintah tersebut harus mengambil dan mengolah data dari BPS lagi. Hal ini tentunya akan memakan waktu yang lama dan bisa saja tejadi kesalahan jika dilakukan secara manual sehingga informasi yang diperoleh pun diragukan sehingga menyebabkan program-program peningkatan kesejahteraan pun tidak tepat sasaran. Pengambilan keputusan untuk menentukan tingkat kesejahteraan penduduk sulit dilakukan pemerintah karena memiliki kriteria masalah yang begitu kompleks. Permasalahan ini biasa disebut dengan istilah Multi Criteria Decission Making (MCDM)[6][7]. Simple Addictive Weighting (SAW) diketahui sebagai salah satu metode yang dapat digunakan untuk permasalahan yang memiliki banyak kriteria[8].

Berdasarkan permasalahan tersebut maka perlu adanya suatu sistem yang dapat mengukur tingkat kesejahteraan setiap kabupaten/kota. Dimana informasi yang dihasilkan dapat membantu pihak pengambil keputusan. Dalam penelitian ini digunakan beberapa indikator atau kriteria yang dianggap mampu mempengaruhi penentuan tingkat kesejahteraan diantaranya pendidikan, kesehatan, fertilitas dan keluarga berencana, perumahan, serta teknologi informasi dan komunikasi. SAW dipilih dan dianggap efektif untuk menyelesaikan masalah ini[9]. Hasil penelitian ini selanjutnya dibuat dalam bentuk aplikasi komputer berbasis web. Aplikasi berbasis web dipilih karena akses sistem dianggap cepat dan dan mudah digunakan[10].

\section{METODE PENELITIAN}

\subsection{Kerangka Pemikiran}

Kerangka pemikiran adalah narasi (uraian) atau pernyataan (proposisi) tentang kerangka konsep pemecahan masalah yang telah diidentifikasi atau telah dirumuskan. Kerangka pemikiran dapat dilihat pada gambar 1 berikut :

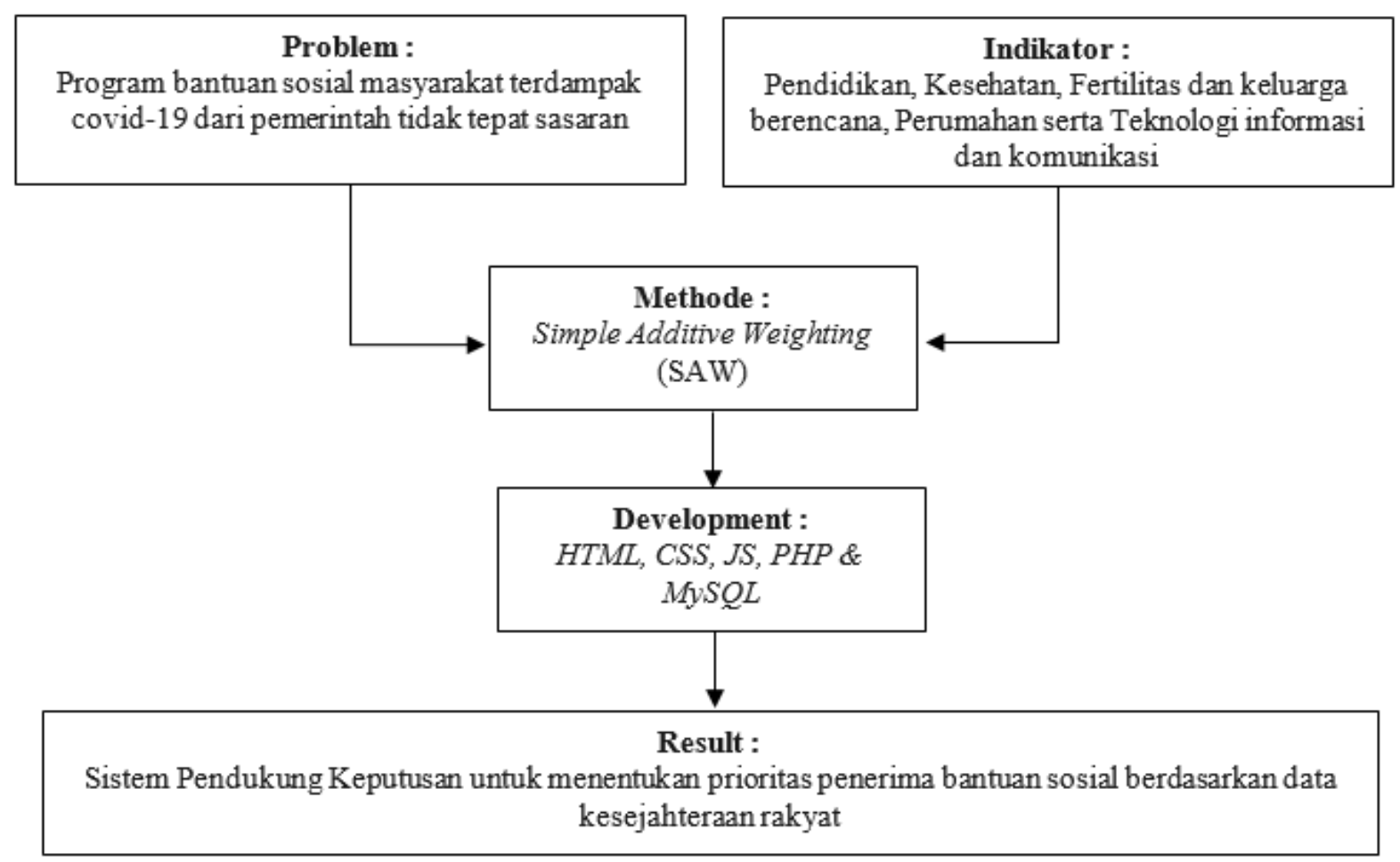

Gambar 1. Kerangka pemikiran

Pada permasalahan yang berhasil diidentifikasi dalam riset ini adalah program bantuan sosial masyarakat terutama masalah teraktual saat ini tentang bantuan sosial untuk masyarakat terdampak covid-19 dari pemerintah dianggap oleh banyak pihak tidak tepat sasaran sehingga dapat menyebabkan kerugian negara. Dalam hal ini pemerintah perlu menggunakan kriteria yang pasti untuk menentukan data penerima bantuan sosial. Sedangkan pada sisi lain BPS melaporkan tentang kesejahteraan rakyat setiap tahun. Oleh karena itu maka pemerintah perlu mempertimbangkan data kesejahteraan rakyat sebagai indikator dalam menentukan prioritas penerima bantuan sosial. Untuk menyelesaikan permasalahan tersebut maka SAW dipilih sebagai metode analisis karena mudah diimplementasikan serta banyak digunakan sebagai acuan dalam menentukan suatu keputusan pada berbagai kasus[11][12][13]. Pengembangan sistem berbagai bahasa pemrograman web diantaranya Hypertext Markup 
Language (HTML), Cascading Style Sheet (CSS), Javascript (JS), dan PHP. Kemudian untuk penyimpanan data digunakan MySQL. Basisdata MySQL dipilih karena gratis dan banyak digunakan[10][14][15]. Selain itu juga MySQL memiliki akses data yang cepat. Dengan demikian maka hasil dari riset ini berupa Sistem Pendukung Keputusan (SPK) untuk menentukan prioritas penerima bantuan sosial berdasarkan data kesejahteraan rakyat.

\subsection{Indikator Kesejahteraan}

Data yang digunakan dalam penelitian ini adalah data simulasi yang dibuat berdasarkan karakteristik dari sebuah data nyata. Data yang disimulasikan ini diperoleh dari Indikator dan Statistik Kesejahteraan Rakyat Provinsi Lampung 2019 yang dipublikasikan BPS Provinsi Lampung[16][17]. Data yang digunakan diantaranya adalah Pendidikan, Kesehatan, Fertilitas dan keluarga berencana, Perumahan serta Teknologi informasi dan komunikasi.

\subsection{Simple Additive Weighting (SAW)}

Metode SAW merupakan suatu metode yang biasa diterapkan pada suatu sistem pendukung keputusan dalam penyelesaian masalah dengan banyak kriteria penentu dan alternatif. Pada dasarnya pengambilan keputusan adalah suatu pendekatan sistematis pada hakekat suatu masalah, pengumpulan fakta-fakta, penentuan yang matang dari alternatif yang dihadapai dan pengambilan tindakan yang menurut perhitungan merupakan tindakan yang paling tepat [8].

$$
r_{i j}= \begin{cases}\frac{x_{i j}-}{\operatorname{Max} x_{i j}} & \text { jika } \mathrm{j} \text { adalah atribut keuntungan (benefit) } \\ \underline{\operatorname{Min} x_{i j}} & \text { jika j adalah atribut biaya (cost) } \\ x_{i j} & \end{cases}
$$

Keterangan:

$\mathrm{r}_{\mathrm{ij}} \quad$ : Rating kinerja ternormalisasi

$\operatorname{Max}_{\mathrm{i}} \quad$ : Nilai maksimum dari setiap baris dan kelompok

$\mathrm{Min}_{\mathrm{i}} \quad$ : Nilai minimum dari setiap baris dan kolom

$\mathrm{X}_{\mathrm{ij}} \quad$ : Baris dan kolom dari matriks

Nilai prefensi untuk setiap alternatif $\left(\mathrm{V}_{\mathrm{i}}\right)$ diberikan sebagai:

$$
\mathrm{V} i=\sum_{j=1}^{n} \mathrm{Wi}^{r i j}
$$

Keterangan:

$\mathrm{V}_{\mathrm{i}} \quad$ : Nilai akhir dari alternatif

$\mathrm{W}_{\mathrm{i}}$ : Bobot yang telah ditentukan

$\mathrm{R}_{\mathrm{ij}}$ : Normalisasi matriks

Nilai $\mathrm{V}_{\mathrm{i}}$ yang lebih besar mengindikasikan bahwa alternatif $\mathrm{A}_{\mathrm{i}}$ lebih terpilih.

\subsection{Pemrosesan dan Perhitungan Metode SAW}

Pada perhitungan data kependudukan, data akan dihitung dengan rumus SAW yaitu dengan menentukan bobot dari masing - masing kriteria. Metode SAW dilakukan dengan menganalisis beberapa kriteria untuk mengukur tingkat kesejahteraan rakyat. Adapun kriteria yang dimaksud disajikan pada Tabel 1.

Tabel 1. Kriteria tingkat kesejahteraan rakyat

\begin{tabular}{lc}
\hline Kriteria & Atribut \\
\hline Pendidikan & Cost \\
Kesehatan & Cost \\
Fertilitas dan keluarga berencana & Benefit \\
Perumahan & Cost \\
Teknologi informasi dan komunikasi & Cost \\
\hline
\end{tabular}


Setiap kriteria memiliki kompleksitas yang dituliskan dalam beberapa jenis kemudian disebut sub kriteria. Berikut ini merupakan sub kriteria dari kriteria pertama yaitu pendidikan yang disajikan pada Tabel 2.

Tabel 2. Sub kriteria pendidikan

\begin{tabular}{lc}
\hline Sub Kriteria & Bobot \\
\hline Memiliki anggota keluarga yang sedang Kuliah & 4 \\
Memiliki anggota keluarga yang sedang SMA & 3 \\
Memiliki anggota keluarga yang sedang SMP & 2 \\
Memiliki anggota keluarga yang sedang SD & 1 \\
\hline
\end{tabular}

Kriteria ke-dua adalah kesehatan dengan beberapa sub kriteria yang selanjutnya disajikan pada Tabel 3.

Tabel 3. Sub kriteria kesehatan

\begin{tabular}{lc}
\hline Sub Kriteria & Bobot \\
\hline Memiliki asuransi kesehatan biaya pribadi & 1 \\
Memiliki asuransi kesehatan biaya pemerintah & 2 \\
Memiliki KTP sesuai daerah domisili, tidak memiliki asuransi & 3 \\
Tidak memiliki KTP sesuai daerah domisili dan tidak memiliki asuransi & 4 \\
\hline
\end{tabular}

Kemudian kriteria yang ke-tiga adalah fertilitas dan keluarga berencana, selanjutnya disajikan sub kriteria seperti pada Tabel 4.

Tabel 4. Sub kriteria fertilitas dan keluarga berencana

\begin{tabular}{lc}
\hline Sub Kriteria & Bobot \\
\hline Memiliki jumlah anak $<=2$ & 1 \\
Memiliki jumlah anak 3-4 & 2 \\
Memiliki jumlah anak $6-8$ & 3 \\
Memiliki jumlah anak $>8$ & 4 \\
\hline
\end{tabular}

Sedangkan kriteria ke-empat adalah perumahan dengan sub kriteria yang disajikan pada Tabel 5

Tabel 5. Sub kriteria perumahan

\begin{tabular}{lc}
\hline Sub Kriteria & Bobot \\
\hline Memiliki $>1$ rumah & 1 \\
Memiliki 1 rumah & 2 \\
Menyewa rumah & 3 \\
Menyewa kamar & 4 \\
\hline
\end{tabular}

Berikutnya adalah kriteria terakhir yaitu teknologi informasi dan komunikasi. Memiliki beberapa sub kriteria yang disajikan pada Tabel 6 .

Tabel 6. Sub kriteria teknologi informasi dan komunikasi

\begin{tabular}{lc}
\hline Sub Kriteria & Bobot \\
\hline Semua anggota keluarga memiliki lebih dari 1 smartphone/komputer/laptop & 1 \\
Semua anggota keluarga memiliki 1 smartphone/ komputer/laptop & 2 \\
Sebagian anggota keluarga memiliki smartphone/ komputer/laptop & 3 \\
Semua anggota keluarga tidak memiliki smartphone/ komputer/laptop & 4 \\
\hline
\end{tabular}

Nama-nama kepala keluarga disebut sebagai alternatif yang diukur tingkat kesejahteraannya. Sedangkan urutan alternatif akan menentukan peringkat kesejahteraan setiap kepala keluarga yang selanjutnya disajikan pada Tabel 7. 
Tabel 7. Alternatif nama kepala keluarga

\begin{tabular}{ll}
\hline No & Nama Kepala Keluarga \\
\hline 1 & Bapak A \\
2 & Bapak B \\
3 & Bapak C \\
4 & Bapak D \\
5 & Bapak E \\
6 & Bapak F \\
7 & Bapak G \\
$\mathbf{x}$ & Dan seterusnya \\
\hline
\end{tabular}

\subsection{Metode Pengembangan Sistem}

Dalam rangka membangun purwa rupa yang baik dan sesuai dengan target yang ingin dicapai maka dipilih metode pengembangan sistem yang sesuai dengan keadaan peneliti. Oleh karena itu model diimplementasikan dengan membuat purwa rupa yang dibangun menggunakan metode extrim programming $(X P)$. Tahapan pengembangan sistem yang dilakukan menggunakan metode XP disajikan pada gambar 2.

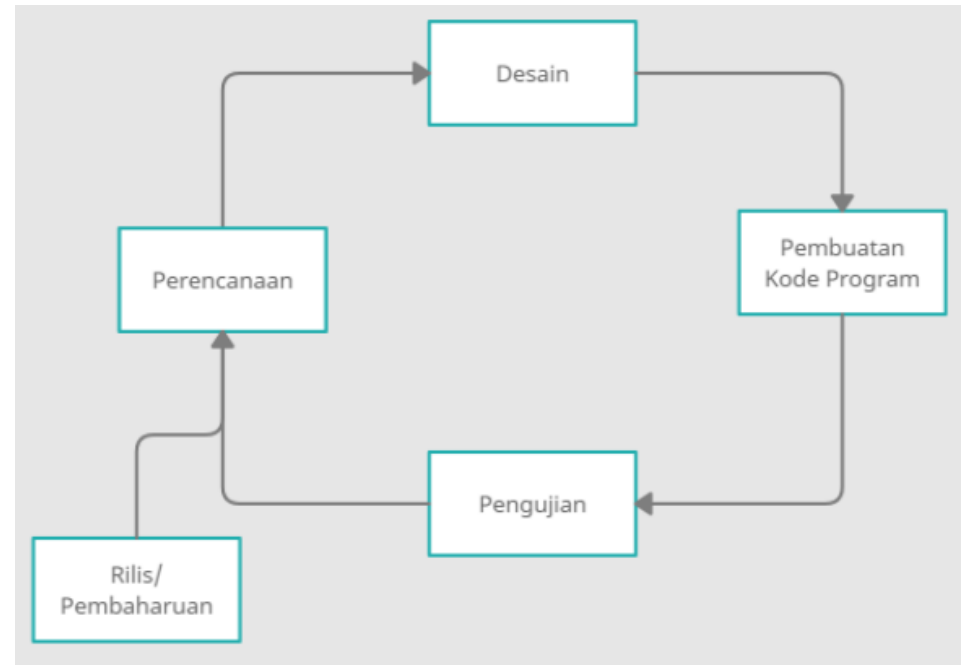

Gambar 2. Metode XP

Tahap perencanaan dilakukan indentifikasi kebutuhan sistem dengan mengumpulkan kebutuhan pengguna. Pada tahapan ini dilakukan agar diketahui kebutuhan input dan output serta fungsionalitas sistem yang akan dikembangkan. Selanjutnya pada tahapan desain dibuat model diantaranya desain sistem menggunakan UML dan desain penyimpanan data menggunakan Enhanced Entity Relationship (EER). Kemudian pada pembuatan kode program purwa rupa dibuat menggunakan beberapa bahasa pemrograman web diantaranya HTML, CSS, Javascript dan PHP yang dikomunikasikan dengan basisdata MySQL. Selanjutnya dilakukan pengujian untuk memastikan apakah purwa rupa yang dibangun sudah sesuai dengan perencanaan dan dapat memberikan hasil yang bisa diukur menurut pengetahuan.

\subsection{Rancangan Struktur Basis Data}

Rancangan struktur sistem basis data dibuat menggunakan model (EER). Model ini digunakan karena sistem yang dikembangkan cukup kompleks sehingga dianggap cocok untuk menyelesaikan masalah ini[18]. Sementara alat yang digunakan untuk mendesain model ini adalah MySQL Workbench sebagai Grapical User Interface (GUI) untuk mengelola server basisdata MySQL. Model EER yang dikembangkan selanjutnya disajikan pada Gambar 3 berikut. 

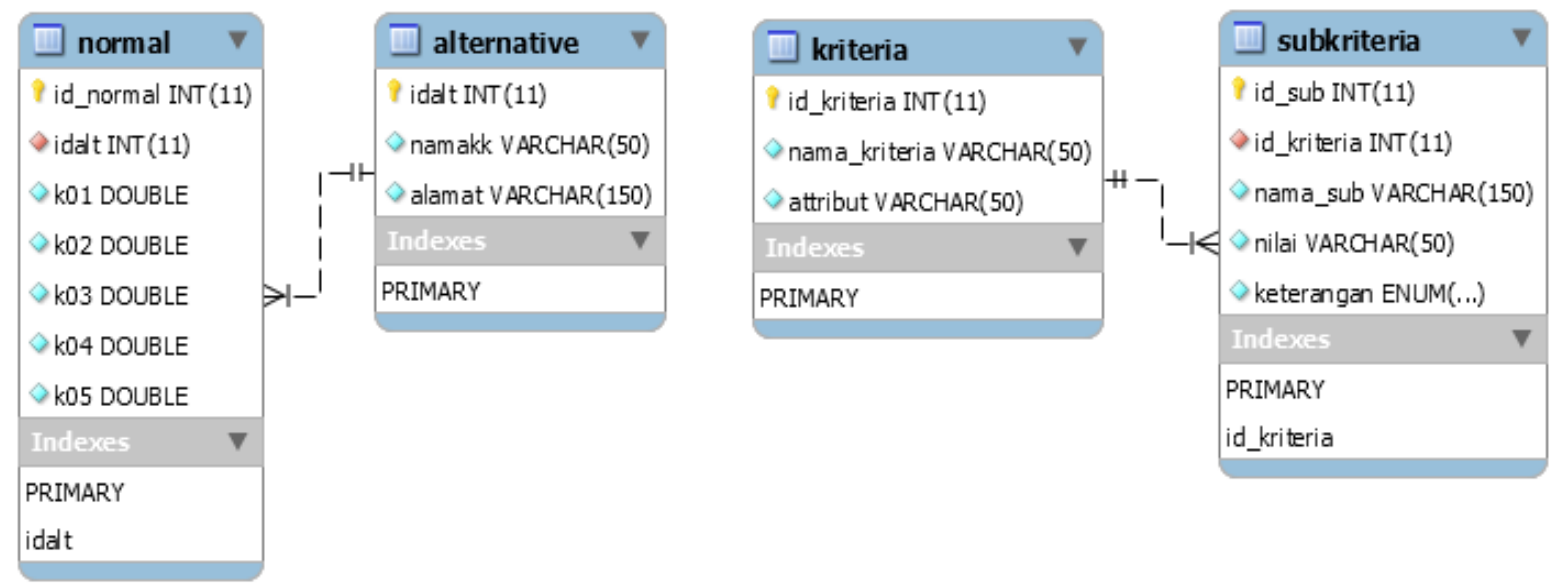

Gambar 3. Diagram EER

\subsection{Analisis Usecase}

Analisis fungsionalistas sitem perlu dilakukan untuk menentukan peranan dari aktor-aktor yang terlibat dalam menentukan kebijakan. Analisis usecase selanjutnya disajikan pada tabel 8 .

Tabel 8. analisis usecase

\begin{tabular}{|c|c|c|c|}
\hline No & Nama Usecase & Aktor & Deskripsi \\
\hline 1 & Dashboard & Ketua RT & Berisi informasi deskripsi perangkat lunak \\
\hline 2 & Alternatif & Ketua RT & Modul manajerial data calon penerima bantuan \\
\hline 3 & Kriteria & Ketua RT & $\begin{array}{l}\text { Modul manajerial kriteria apa saja yang digunakan untuk menilai } \\
\text { kelayakan calon penerima BST }\end{array}$ \\
\hline 4 & Sub kriteria & Ketua RT & $\begin{array}{l}\text { Modul manajerial data bobot keadaan calon penerima BST sesuai dengan } \\
\text { kriteria }\end{array}$ \\
\hline 5 & Normalisasi & Ketua RT & Modul data keadaan calon penerima BST sesuai dengan kriteria \\
\hline 6 & Perhitungan & Ketua RT & Modul analisis data menggunakan metode SAW \\
\hline 7 & Kesimpulan & Ketua RT & $\begin{array}{l}\text { Modul yang menunjukkan nilai hasil analisis terhadap calon penerima } \\
\text { BST berdasarkan kriteria }\end{array}$ \\
\hline
\end{tabular}

\subsection{Diagram Usecase}

Hasil analisisi usecase selanjutnya dibuat pemodelan menggunakan Unifiled Modeling Language (UML). Diagram usecase disajikan pada gambar 4 berikut :

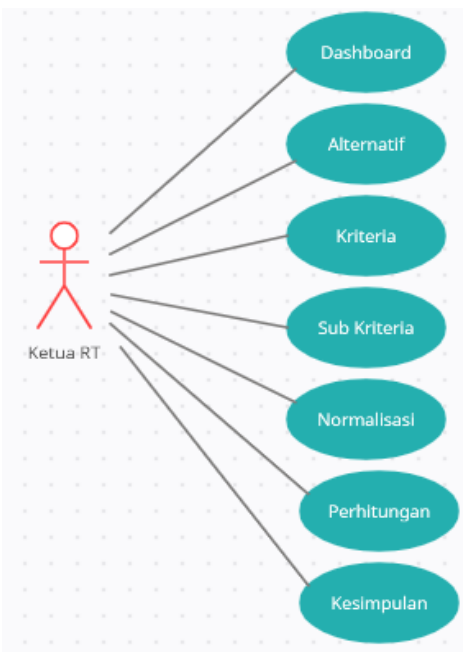

Gambar 4. Diagram usecase 


\section{HASIL DAN PEMBAHASAN}

\subsection{Program}

Pada sistem pendukung keputusan yang dibangun terdapat beberapa input data diantaranya alternatif yaitu daftar orang-orang calon penerima bantuan sosial, kriteria yaitu indikator yang digunakan dalam menentukan kesejahteraan rakyat serta sub kriteria yaitu klasifikasi setiap kriteria. Setiap sub kriteria memiliki nilai yang berbeda yaitu yang disesuaikan dengan tingkat kepentingannya. Berikut ini disajikan tampilan dashboard purwarupa pada gambar 5 .

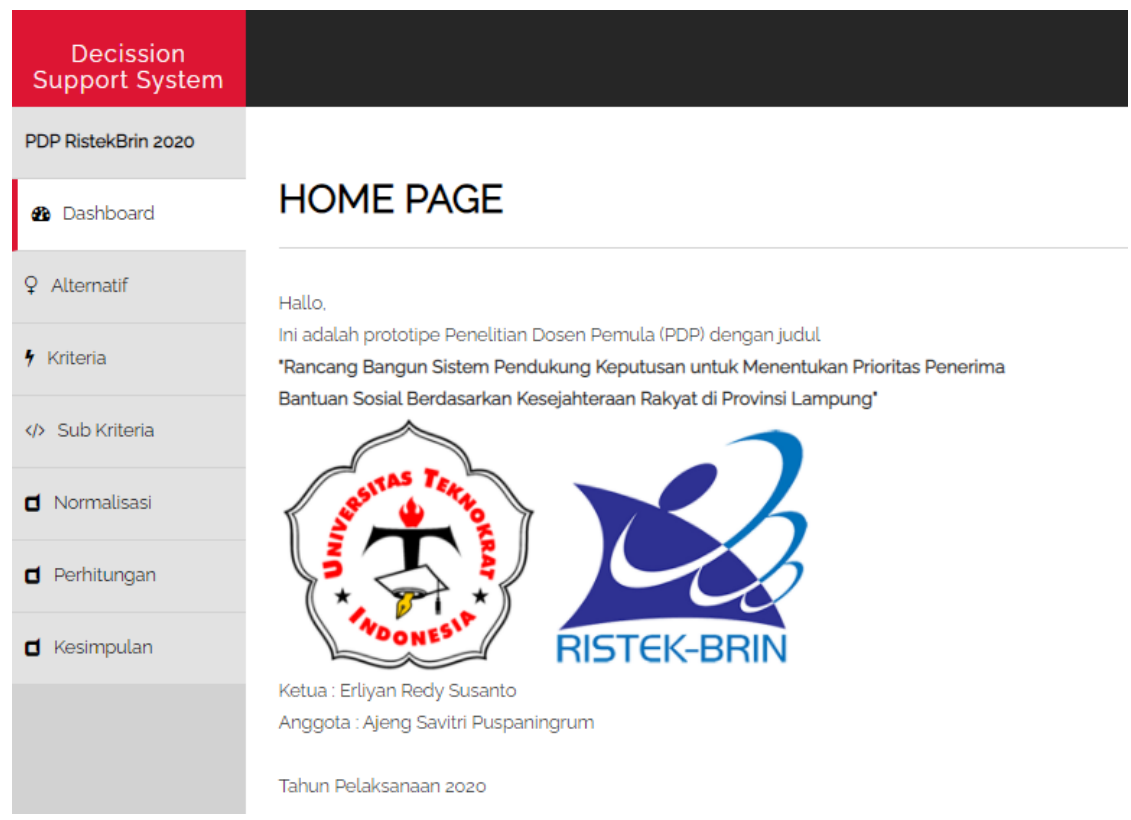

Gambar 5. Dashboard

Langkah berikutnya adalah menentukan data alternatif yaitu dengan melakukan pendataan penduduk sebagai calon penerima bantuan. Selanjutnya dilakukan penentuan kriteria calon penerima bantuan dan ditentukan juga data sub kriteria dengan menuntukan bobot untuk setiap data sub kriteria. Berikut ini disajikan proses pemilihan tampilan penentuan sub kriteria berdasarkan kondisi masyarakat yang disajikan pada Gambar 6 .

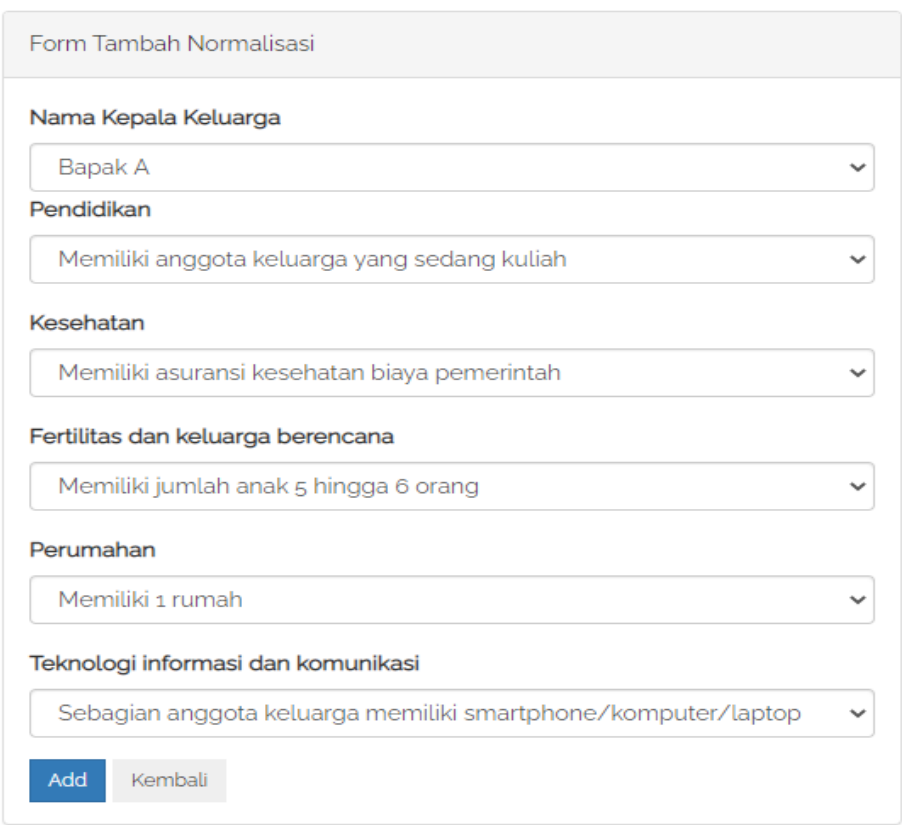

Gambar 6. Menentukan sub kriteria berdasarkan kondisi masyarakat 
Data yang diinputkan selanjutnya selanjutnya dianalisa menggunakan SAW untuk memperoleh nilai perhitungan bobot. Sedangkan tampilan hasil perhitungan bobot disajikan pada Gambar 7 berikut :

\begin{tabular}{|c|c|c|c|c|c|c|}
\hline \multicolumn{7}{|c|}{ Bobot: (5) (5) (5) (5) (5) } \\
\hline No & $\begin{array}{l}\text { Nama } \\
\text { Kepala } \\
\text { Keluarga }\end{array}$ & $\begin{array}{l}\text { Ko1. } \\
\text { Pendidikan }\end{array}$ & $\begin{array}{l}\text { Ko2. } \\
\text { Kesehatan }\end{array}$ & $\begin{array}{l}\text { Ko3. Fertilitas } \\
\text { dan keluarga } \\
\text { berencana }\end{array}$ & $\begin{array}{l}\text { Ko4. } \\
\text { Perumahan }\end{array}$ & $\begin{array}{l}\text { Ko5. } \\
\text { Teknologi } \\
\text { informasi } \\
\text { dan } \\
\text { komunikasi }\end{array}$ \\
\hline 1 & Bapak A & 3 & 3 & 4 & 4 & 3 \\
\hline 2 & Bapak B & 4 & 4 & 2 & 3 & 4 \\
\hline 3 & Bapak C & 4 & 4 & 4 & 4 & 4 \\
\hline 4 & Bapak D & 4 & 3 & 4 & 3 & 3 \\
\hline 5 & Bapak E & 4 & 3 & 3 & 4 & 1 \\
\hline 6 & Bapak F & 4 & 3 & 3 & 2 & 3 \\
\hline 7 & Bapak G & 4 & 4 & 4 & 2 & 2 \\
\hline
\end{tabular}

Gambar 7. Hasil perhitungan bobot

Selanjutnya hasil normalisasi data disajikan pada Gambar 8

\begin{tabular}{|c|c|c|c|c|c|c|}
\hline \multicolumn{7}{|c|}{ Normalisasi Data } \\
\hline No & $\begin{array}{l}\text { Nama } \\
\text { Kepala } \\
\text { Keluarga }\end{array}$ & $\begin{array}{l}\text { Ko1. } \\
\text { Pendidikan }\end{array}$ & $\begin{array}{l}\text { Ko2. } \\
\text { Kesehatan }\end{array}$ & $\begin{array}{l}\text { Ko3. Fertilitas } \\
\text { dan keluarga } \\
\text { berencana }\end{array}$ & $\begin{array}{l}\text { Ko4. } \\
\text { Perumahan }\end{array}$ & $\begin{array}{l}\text { Ko5. } \\
\text { Teknologi } \\
\text { informasi } \\
\text { dan } \\
\text { komunikasi }\end{array}$ \\
\hline 1 & Bapak A & 0.33 & 0.75 & 1 & 1 & 0.75 \\
\hline 2 & Bapak B & 0.25 & 1 & 0.5 & 0.75 & 1 \\
\hline 3 & Bapak C & 0.25 & 1 & 1 & 1 & 1 \\
\hline 4 & Bapak D & 0.25 & 0.75 & 1 & 0.75 & 0.75 \\
\hline 5 & Bapak E & 0.25 & 0.75 & 0.75 & 1 & 0.25 \\
\hline 6 & Bapak F & 0.25 & 0.75 & 0.75 & 0.5 & 0.75 \\
\hline 7 & Bapak G & 0.25 & 1 & 1 & 0.5 & 0.5 \\
\hline
\end{tabular}

Gambar 8. Normalisasi data

Sehingga diperoleh hasil perengkingan data yang disajikan pada gambar 9 berikut 


\begin{tabular}{|l|l|l|}
\hline Perangkingan Data & \\
\hline No & Nama Kepala Keluarga & Hasil Perhitungan \\
\hline 1 & Bapak A & 19.17 \\
\hline 2 & Bapak B & 17.5 \\
\hline 3 & Bapak C & 21.25 \\
\hline 4 & Bapak D & 17.5 \\
\hline 5 & Bapak E & 15 \\
\hline 6 & Bapak F & 15 \\
\hline 7 & Bapak G & 16.25 \\
\hline
\end{tabular}

Gambar 9. Perangkingan data

Berdasarkan data tersebut dapat diketahui bahwa analisis menggunakan metode SAW menunjukkan bahwa Bapak C memiliki bobot lebih besar dibandingkan dengan nama kepala keluarga yang lain. Dengan demikian dapat disimpulkan bahwa seharusnya beliau adalah orang yang lebih diprioritaskan / perlu diberikan perhatian yang lebih dalam memperoleh bantuan sosial dari pemerintah.

\subsection{Pengujian purwarupa}

Purwarupa dalam bentuk software yang sudah dibangun selanjutnya dilakukan pengujian dengan membandingkan hasil analisis software dengan pendapat pakar. Ketua RT pada Kelurahan Sukajawa Kecamatan Tanjung Karang Barat Kota Bandar Lampung selanjutnya dipilih sebagai pakar. Dalam pengujian kali ini digunakan 7 buah data sebagai contoh pengujian yang selanjutnya disajikan pada tabel 8 .

Tabel 8. Hasil Pengujian

\begin{tabular}{|c|c|c|c|c|c|c|c|c|c|}
\hline \multicolumn{6}{|c|}{ Variabel } & \multirow[b]{2}{*}{ Nilai } & \multirow[b]{2}{*}{ Sistem } & \multirow[b]{2}{*}{ Pakar } & \multirow[b]{2}{*}{ Hasil } \\
\hline $\begin{array}{l}\mathrm{N} \\
\mathrm{o}\end{array}$ & $\begin{array}{l}\text { Pendi } \\
\text { dikan }\end{array}$ & $\begin{array}{l}\text { Kese } \\
\text { hatan }\end{array}$ & $\begin{array}{l}\text { Fertilitas } \\
\text { dan } \\
\text { keluarga } \\
\text { berencana }\end{array}$ & $\begin{array}{l}\text { Per } \\
\text { uma } \\
\text { han }\end{array}$ & $\begin{array}{c}\text { Teknologi } \\
\text { informasi } \\
\text { dan } \\
\text { komunikasi }\end{array}$ & & & & \\
\hline 1 & 4 & 4 & 4 & 4 & 4 & 21,25 & Bapak C & Bapak C & Benar \\
\hline 2 & 3 & 3 & 4 & 4 & 3 & 19,17 & Bapak A & Bapak A & Benar \\
\hline 3 & 4 & 4 & 2 & 3 & 4 & 17,5 & Bapak B & Bapak D & Salah \\
\hline 4 & 4 & 3 & 4 & 3 & 3 & 17,5 & Bapak D & Bapak B & Salah \\
\hline 5 & 4 & 4 & 4 & 2 & 2 & 16,25 & Bapak G & Bapak G & Benar \\
\hline 6 & 4 & 3 & 3 & 4 & 1 & 15 & Bapak E & Bapak E & Benar \\
\hline 7 & 4 & 3 & 3 & 2 & 3 & 15 & Bapak F & Bapak F & Benar \\
\hline
\end{tabular}

Berdasarkan hasil pengujian terhadap 7 data tersebut dapat diketahui terdapat perbedaan urutan antara sistem dan pakar dan didapatkan 5 hasil benar urutannya dan 2 hasil salah urutannya. Akan tetapi jika dilihat berdasarkan nilai yang diperoleh data uji ke-3 dan ke-4 memiliki nilai yang sama. Perbedaan urutan dapat terjadi karena adanya pembacaan urutan data pada database berdasarkan id sebagai kunci utama. Sehingga diperoleh nilai akurasi pengujian sistem sebesar $70 \%$.

\section{KESIMPULAN}

Berdasarkan hasil penelitian yang sudah dilakukan maka dengan ini dapat disimpulkan bahwa metode SAW efektif digunakan untuk menganalisis data yang berkaitan dengan pembuatan keputusan terutama dalam hal menentukan prioritas pemberian bantuan sosial kepada masyarakat. Konsep yang diadopsi dari metode SAW adalah analisis dilakukan terhadap kriteria yang terdiri dari 2 (dua) variabel yaitu biaya/cost dan 
keuntungan/benefit. Kriteria yang digunakan dalam pengambilan keputusan adalah menggunakan indikator kesejahteraan rakyat Provinsi Lampung 2019. Indikator kesejahteraan rakyat yang dimaksud diantaranya adalah pendidikan, kesehatan, perumahan, teknologi informasi dan komunikasi yang disebut sebagai komponen cost/biaya. Sedangkan Fertilitas dan keluarga berencana disebut sebagai komponen benefit/keuntungan.

Program komputer berbasis web selanjutnya dibangun untuk mengimplementasikan hasil penelitian dalam bentuk purwa rupa. Purwa rupa yang sudah dikembangkan selanjutnya diuji menggunakan data sample pada level RT. Output program selanjutnya dibandingkan dengan data penerima bantuan yang sudah dikeluarkan pemerintah. Hasil pengujian menunjukkan bahwa sistem yang dibangun mampu menampilkan output berupa rekomendasi penerima bantuan sosial dengan akurasi 70\%. Hasil akurasi pengujian terhadap data penerima bantuan sosial tidak digunakan untuk menilai kebenaran data yang dikeluarkan pemerintah.

Model yang dikembangkan menggunakan metode SAW ini dapat juga diterapkan untuk menentukan prioritas penerima bantuan sosial yang lainnya. Masalah yang paling krusial adalah menentukan kriteria (indikator) dan jenis kriteria (cost atau benefit). Penelitian ini dapat dikembangkan dengan menggunakan kriteria yang lain disesuaikan dengan jenis bantuan yang akan diberikan karena biasanya setiap jenis bantuan memiliki beberapa syarat yang berbeda.

\section{UCAPAN TERIMAKASIH}

Terima kasih disampaikan kepada pihak-pihak yang telah mendukung / sponsor penelitian ini yaitu Kemenristek / BRIN Republik Indonesia. Kami ucapkan terimakasih juga kepada segenap jajaran Dinas Sosial Kota Bandar Lampung serta semua pihak yang telah bersedia membantu dalam pelaksanaan penelitian.

\section{REFERENCES}

[1] F. Riana, "Bansos Covid Tak Tepat Sasaran, Pusat: Pemda Harusnya Verifikasi - Nasional Tempo.co," https://nasional.tempo.co/, 2020. .

[2] H. Siagian, "Publik Anggap Bantuan Sosial Covid-19 Banyak tidak Tepat Sasaran," https://mediaindonesia.com/, 2020. .

[3] Ihsanuddin, "Survei Puspek Unair: Bansos Covid-19 Belum Tepat Sasaran,” https://nasional.kompas.com/, 2020. .

[4] Ihsanuddin, "Ada 7 Bantuan Pemerintah Selama Pandemi Covid-19, Berikut Rinciannya... Halaman all Kompas.com.” https://nasional.kompas.com/read/2020/08/26/09222471/ada-7-bantuan-pemerintah-selamapandemi-covid-19-berikut-rinciannya?page=all (diakses Agu 28, 2020).

[5] M. Louisa, R. Kaho, A. R. Tanaamah, dan A. D. Wowor, "Penerapan Metode Simple Additive Weighting Pada Penentuan Tingkat Kesejahteraan Penduduk Propinsi Nusa Tenggara Timur,” Proc. KNASTIK, vol. 01, no. 01, hal. 123-139, Des 2016, Diakses: Agu 20, 2019. [Daring]. Tersedia pada: https://vlabti.ukdw.ac.id/ojs/index.php/proceedings/article/view/516.

[6] J. Rezaei, "Best-worst multi-criteria decision-making method," Omega, vol. 53, hal. 49-57, Jun 2015, doi: 10.1016/j.omega.2014.11.009.

[7] I. B. Huang, J. Keisler, dan I. Linkov, "Multi-criteria decision analysis in environmental sciences: Ten years of applications and trends," Sci. Total Environ., vol. 409, no. 19, hal. 3578-3594, Sep 2011, doi: 10.1016/j.scitotenv.2011.06.022.

[8] A. Alinezhad, A. Amini, dan A. Alinezhad, "Sensitivity analysis of simple additive weighting method (SAW): the results of change in the weight of one attribute on the final ranking of alternatives," J. Ind. Eng., vol. 4, hal. 13-18, 2009.

[9] D. O. Yurnas, D. Sarwinda, dan F. Muttakin, "Masyarakat Dengan Pendekatan Data Mining Terintegrasi Sistem Pendukung Keputusan," in Prosiding Seminar Ilmiah Nasional Teknologi Komputer (SENATKOM 2015), 2015, vol. 1, hal. 14-19.

[10] E. R. Susanto dan F. Ramadhan, "RANCANG BANGUN APLIKASI BERBASIS WEB PERIZINAN PRAKTIK TENAGA KESEHATAN MENGGUNAKAN FRAMEWORK CODEIGNITER PADA DINAS KESEHATAN KOTA METRO,” J. Tekno Kompak, 2017, doi: 10.33365/jtk.v11i2.173.

[11] I. Kaliszewski dan D. Podkopaev, "Simple additive weighting-A metamodel for multiple criteria decision analysis 
methods," Expert Syst. Appl., vol. 54, hal. 155-161, Jul 2016, doi: 10.1016/j.eswa.2016.01.042.

[12] N. Nuraeni, "PENERAPAN METODE SIMPLE ADDITIVE WEIGHTING (SAW) DALAM SELEKSI CALON KARYAWAN,” Swabumi, 2018, doi: 10.31294/swabumi.v6i1.3317.

[13] A. Setiadi, Y. Yunita, dan A. R. Ningsih, "Penerapan Metode Simple Additive Weighting(SAW) Untuk Pemilihan Siswa Terbaik,” J. Sisfokom (Sistem Inf. dan Komputer), 2018, doi: 10.32736/sisfokom.v7i2.572.

[14] M. Roziq Zanuddin, Herman Adi Riyanto, Sadikin, "SISTEM INFORMASI PERPUSTAKAAN UMUM GRATI KABUPATEN PASURUAN BERBASIS WEB MENGGUNAKAN PROGRAM PHP DAN DATABASE MYSQL," J I M P - J. Inform. Merdeka Pasuruan, vol. 1, no. 2, Agu 2016, doi: 10.37438/jimp.v1i2.13.

[15] M. Destiningrum dan Q. J. Adrian, "Sistem Informasi Penjadwalan Dokter Berbassis Web Dengan Menggunakan Framework Codeigniter (Studi Kasus: Rumah Sakit Yukum Medical Centre),” J. Teknoinfo, 2017, doi: 10.33365/jti.v11i2.24.

[16] BPS Lampung, INDIKATOR KESEJAHTERAAN RAKYAT PROVINSI LAMPUNG. Bandar Lampung: Badan Pusat Statistik Provinsi Lampung, 2019.

[17] BPS Lampung, “Statistik Kesejahteraan Rakyat Provinsi Lampung 2019,” Bandar Lampung, 2019.

[18] M. M. Alkoshman, “Unified Modeling Language and Enhanced Entity Relationship: An Empirical Study,” Int. J. Database Theory Appl., 2015, doi: 10.14257/ijdta.2015.8.3.18. 